\begin{tabular}{ccc}
\hline Mournals & MARKETING AND BRANDING & INDUSTRIAL \\
RANAGEMENT \\
Almi
\end{tabular}

\title{
An investigation into the impact of ownership structure on the level of cash holdings in the companies accepted in Tehran Stock Exchange Market
}

\author{
Kaveh Azinfar $^{1 *}$, Zahra Shiraseb ${ }^{2}$ \\ ${ }^{1}$ Faculty Member in Accountancy, Islamic Azad University, Babol Branch. Babol, Mazandaran, Iran \\ ${ }^{2}$ M.A. in Accountancy
}

\begin{abstract}
Keywords: Institutional Ownership, Managerial Ownership, Corporate Ownership, Foreign Ownership, Level of Cash Holdings

Correspondence: azinfarbabol@yahoo.com

Liquidity of a company is the ability to meet cash commitments before the deadline. Selecting from cash spending or cash holdings by the managers is of great importance for the owners of the company. Various factors can be effective in determining the level of company's liquidity. Ownership structure of companies is one of these factors, which may lead to companies' behavioral change. This change is derived from monitoring activities by different investors in this structure. This study was an attempt to assess the impact of ownership structure on the level of companies' cash holdings in creating appropriate ownership in connection with creating the level of cash holdings. In this study, ownership structure has been categorized into four types of institutional ownership, managerial ownership, corporate ownership, and foreign ownership. In this regard, the impact of institutional, managerial, corporate and foreign variables on the level of cash holdings has been investigated. For every category of ownership, a hypothesis was proposed and its impact on the level of cash holdings was tested. The statistical sample of the research included 96 companies from 2004 to 2013. The statistical method of testing the hypotheses in this study was multiple regressions through panel data. The findings revealed a significant relationship between institutional, managerial, and foreign ownership and the level of cash holdings; however, there was no significant relationship between corporate ownership of the company and the level of cash holdings.
\end{abstract}

(C)AIMI Journals

\section{Introduction}

The industrial revolution in nineteenth-century initiated the formation of joint-stock companies and paved the way for sharing the ownership of these companies for the public. 
Through this mechanism, the owners of companies assign the administration of the company to the managers. Since cash in hand is a significant part of company's assets and is considered as a crucial resource for every economic unit, providing balance between the existing cash and cash needs is one of the most important factors in the economic health of commercial units and their activities (Ghorbani \& Adili, 2012). During the economic development of companies, which cash reserves increase, the manager's decision on this extra cash is of great importance. In other words, managers decide to whether distribute the cash among shareholders, spend it on domestic expenditures or reserve it. In fact, managers attempt to reserve a level of cash in hand which is optimum, i.e. reserving extra cash does not waste opportunities and lack of liquidity does not cause heavy losses to the company (Aghaee, Nezafat, Nazemi Ardakani, \& Javan, 2009). However, this level of cash holdings is different in various companies.

The important issue, which has been investigated in this study, is the impact that ownerships of company have on the optimum level of cash holdings. To date, there has not been much research which investigated the relationship between ownership structure and the level of cash holdings. However, some researchers such as Ghorbani and Adili (2012), Aghaee et al. (2009) and Rasaian, Rahimi, and Hanjari (2011) have investigated the relationship between different variables like information asymmetry, gross working capital, and the impact of inter-organizational regulatory mechanisms of corporate governance on the level of cash holdings. Malekian and Adili (2013) have studied institutional ownership and cash holdings. Therefore, we believe that this study will add to the literature by examining the relationship between ownership structure and the level of cash holdings.

\section{The Literature Review}

Ownership structure is one of the internal mechanisms of corporate governance and the corporate governance is considered as one of the principal components of development. The pertinent literature indicates that appropriate ownership structure is different according to the environmental conditions of different countries and there is no general pattern in the countries. The main topic in ownership structure is agency problem, because the conflict of interests between managers and shareholders leads to agency costs. If their share is small, the shareholders' motivation and abilities to control management will be weak, thus dispersed ownership creates agency problem in the companies. In contrast, concentrated ownership significantly provides major shareholders with motivation and larger shares in the company increase their motivation for improving company's operation and controlling management (Fazlzadeh, Mohammadzadeh, \& Tahbaz Hendi, 2008). According to Kumar (2004) and Namazi and Kermani (2009), the composition of shareholders is measured through four variables, namely foreign, institutional, corporate and managerial ownership.

Corporate scandals in recent years have challenged the role of corporate governance in effectively monitoring the managers' decisions and companies' performance. Improving such a condition requires an increase in effectively monitoring the managers' decisions and companies' performance (Cornett, Marcus, Saunders, \& Tehranian, 2007). One of the mechanisms of corporate governance, which is of increasing importance, is the emergence of institutional investors as the owners of capital. 
Since the institutional investors are the greatest group of shareholders, their role in monitoring the managers and affecting companies' performance is of great importance and it is expected that the presence of these owners in the composition of shareholders can be effective in the company's performance. Institutional investors are great investors like banks, insurance companies, investment companies, and retirement institutions (Davis, 2002). Since the institutional investors usually hold a considerable percentage of companies' shares and are professional in investment, they show the necessary motivation and ability to monitor the companies. Generally, it is believed that the presence of institutional investors may lead to a change in companies' behaviors and performances. This is derived from the monitoring activities done by the investors like Velury and Jenkins (2006). Davis (2002) stated that institutional investors monitor the company implicitly through gathering information and pricing the management decisions and explicitly through administering the company. Kaplan and Minton (1994) found that the presence of great investors is related to high management relocation, which shows that these shareholders carry the monitoring responsibility.

Institutional shareholders have a controlling role. It means that they pressurize managers into acting in the long-term in a way that the company will not be damaged (Davis, 2002). This ownership is equal to the stocks reserved by government and non-government companies from the total capital stock of the company. These companies include insurance companies, financial institutions, banks, government companies and other components of the government.

Managerial ownership is equal to the stocks reserved by the board of directors (Earnhart \& Lizal, 2006; Kumar, 2004; Namazi \& Kermani, 2009). According to different studies, if managers are the shareholders of their company, their motivation for monitoring will increase. In fact, if managers' share in ownership increases, they will try hard to increase the value of the company. When the manager owns 100 per cent of company's shares, the agency costs of shareholders will be reduced to zero and a positive relationship between the agency costs of shareholders and the separation of ownership and controlling will be established. However, when the managers' ownership falls below 100 per cent, the shareholders' ownership share will be distributed among them relatively. In such a condition, managers are willing to abdicate their responsibilities or consume extra earnings.

Single owners and owner-managers reduce the effect of external control mechanisms and expose the company to self-control with the mediation of strong motivation of management. Therefore, other shareholders invest their resources to control opportunity seeking managers and owners through lower expenses in proportion to the separation of ownership and management.

Fama and Jensen (1983) state that the family companies are more effective and efficient than public joint stock companies, because they include lower control costs. Therefore, these companies have more market value. If family ownership shows an efficient organizational structure, the opportunistic profit management will be limited. However, in companies, which belong to a commercial group this fact may not be reflected. In companies under family ownership, which also belong to a commercial group, there is a strong motivation for taking the ownership away from minor shareholders and opportunistic managers. In fact, public joint 
stock companies are owned by those figures that use them to gather funds from the public and transfer them to other companies in the commercial groups.

Corporate ownership is equal to the stocks reserved by the components of joint stock companies from the total capital stock of the company and includes all sorts of joint stock companies except for those mentioned in the previous section (Earnhart \& Lizal, 2006; Kumar, 2004; Namazi \& Kermani, 2009). This group of shareholders and owners are potentially considered the source of external-organizational effectiveness on the strategy and performance of the business. Entrance of corporate investors changes the dominant thought into getting more profit and performing better. In fact, company's ownership has a positive and significant relationship with its performance. In other words, the effective presence of corporate owners in the ownership structure of companies leads to better performance of companies. Since these investors seek higher profit and better performance, they attempt to accomplish them through influencing companies' ownership structure. In this case, the more concentrated ownership structure and the goal of making profit will result in highly monitoring the performance of the company. Moreover, the companies will report more information about their performance and future profits. Namazi and Kermani (2009) in their research found that if corporate ownership increases, companies will significantly perform better. Thus, there is a direct relationship between corporate ownership and company's performance.

Foreign ownership is equal to the stocks reserved by the foreigners from the total capital stock of the company and includes foreign companies, foreign financial institutions, foreign nationalities, and non-Iranian nationalities (Earnhart \& Lizal, 2006; Kumar, 2004; Namazi \& Kermani, 2009). The Organization for Economic Co-Operation and Development (OECD) has defined corporate governance as the relationships between the management, board of directors, shareholders, and other beneficiaries of the company. An efficient and effective corporate governance system in a company and in the economy establishes trust which is necessary for the appropriate performance of a market economy. According to the theory of corporate governance shareholding, companies must maximize shareholders' wealth and they must have the right to make decisions.

The theory of information asymmetry, the theory of agency, the theory of balance, the pecking order theory of financing, and the theory of free cash flow are related to the level of cash holdings. One of the negative phenomena that usually occur in security markets is information asymmetry which leads to inappropriate economic decisions made by investors. Information asymmetry occurs when one side of transaction contains more information and uses it for communicating with the other side appropriately. This more information mainly brings economic benefits for the side who contains more information. Information asymmetry between the company and investors makes a difference between the internal and external financing costs, so that external financing includes higher costs for the company. In other words, information asymmetry makes external financing more difficult, because individuals in the outside of the company want to make sure that the securities have not priced unreasonably (Opler, Pinkowitz, Stulz, \& Williamson, 1999). In general, information asymmetry has an important impact on financing costs. 
According to this theory of balance, companies determine their optimum cash through keeping a balance between benefits and cash holdings costs (Rasaian et al., 2011). Cash holdings which reduce the risk of financial crisis are considered safe reserves at the time of facing unexpected losses that enable optimum investing policies when the company faces financial limitations and finally contribute to reducing the costs of collecting financial resources through cashing the existing assets. According to this theory, management that maximizes shareholders' wealth should set the company's cash holdings at a level such that the marginal benefit of cash holdings equals the marginal cost of those holdings (Opler et al., 1999).

According to the pecking order theory of financing, management prefers internal financing resources to external resources (Salavati \& Rasaian, 2007). Therefore, it has tendency to hold cash, so that it can provide finances from the company in the first stage without referring to the outside (Ferreira \& Vilela, 2004). This theory is based on the fact that the individuals who are inside the company are more aware than shareholders. If the internal resources of the company are not sufficient for financing optimum investing plans and information asymmetry prevents, managers may ignore profitable projects. In this case, cash is extremely valuable and the only opportunity for issuing shares without losing market value occurs when there is no or few information asymmetry (Drobetz, Gruninger, \& Hirschvogl, 2010). According to this theory, companies regularly consider the capital costly due to information asymmetry; thus, when they need resources, they rely on debts and when they have enough resources they pay the debts before the deadline, invest in profitable projects, or hold cash (Opler et al., 1999).

Regarding financing, the pecking order theory states that the company first finances its investment through retained earnings, then through debts and finally through issuing the shares. The goal of keeping this order is to reduce the costs of information asymmetry and other financing costs (Ferreira \& Vilela, 2004). Therefore, in case of information asymmetry, companies tend to obey the policy of pecking order in financing (Bruinshoofd \& Kool, 2002). Therefore, since the management prefers the internal resources of financing to external resources, it has tendency to hold cash, so that it can provide finances from the company in the first stage without referring to the outside.

According to the theory of agency, the problems of agency are one of the most important determining factors in companies' cash holdings. The agency costs can be used for justifying the behavior of cash holdings by the management. Concerning the size of the company, it can be stated that the bigger a company is, the more authorized the management will be; thus, the probability of holding extra cash will increase. On the other hand, in companies with low debts, it is expected that more cash will be held, because low debt will reduce the monitoring by capital markets and management will possess more authority. It is expected that the companies, which have the opportunity for valuable investments and their external financing costs are high, hold more cash, because in case of lacking cash, the company will lose more valuable projects (Dittmar, Mahrt-Smith, \& Servaes, 2003).

According to the theory of free cash flow, free cash flow is cash flow in excess of that required to fund all of a company's projects that have positive net present values when discounted at the relevant cost of capital. Accordingly, managers are willing to hold cash in 
order to increase their controlled resources and represent a sense of justice when making investing decisions. Payments to shareholders will reduce the power of managers and potentially subject them to monitoring by capital markets that occurs when a company must obtain new capital. However, internal financing enables managers to avoid being monitored (Jensen, 1986).

This theory states that more internal cash allows managers to avoid market control. In this case, they do not need the consent of shareholders and are free to make investment decision. Managers are reluctant to pay cash (like dividend); in contrast, they are willing to invest, even when there is no investment or positive net present value (Izadinia \& Rasaian, 2010). The benefit conflicts between shareholders and managers over the policies of paying dividend are sharper, especially when the organizations have considerable free cash flows.

Keynes (1936) considered three motives for holding cash, namely transacting, taking precautionary measures and dealing with risky situations. The motive for transacting more is due to the costly use of other assets (except for cash) in commercial transactions. Therefore, it can be stated that those companies facing lack of internal resources can sell assets, increase debts, issue new stocks, or avoid paying cash dividend in order to increase their resources. It is expected that those companies, which face more transactions costs, hold more cash assets. On the other hand, the precautionary-motive is about dealing with the risk of liquidity lack, using commercial opportunities, and avoiding bankruptcy. In this regard, companies hold cash to deal with unexpected events and in case the cost of other financing resources is too high, they will use cash holdings to finance their investments (Ozkan \& Ozkan, 2004).

Various factors have impact on cash holdings by the companies. One of them is transaction. Companies attempt to hold a sufficient level of cash to transact and avoid transactions' costs related to changing non-cash assets into cash assets. Although according to empirical evidence, transactions-motive is the reason of cash holdings in the companies and the increase in the level of cash holdings in the recent years is more influenced by the companies' precautionary-motive. Companies attempt to increase their liquidity to avoid the risk of competition and negligence in their necessary investments (Opler et al., 1999).

A company that lacks cash increases its capital through capital market, cashes its assets, reduces profit sharing and investments, renegotiates its financial contracts or performs a combination of mentioned actions. Increasing capital is costly, regardless of whether the company provides it through selling assets or through capital markets. The cost is categorized into fixed and variable costs and the latter is in proportion to the price of increasing capital. The fixed cost of accessibility to foreign capital markets leads the company to increase its capital rarely and use the cash holdings instead. However, cash holdings include opportunity cost. On the other hand, lack of cash causes major losses for the company. Therefore, for a particular amount of net assets, there will be an optimum price of cash. In other words, there is an optimum level of cash, which is not more than needed, so that the company will not incur losses due to the stagnating capital and is not less than the minimum level, so that the company will not face liquidity lack.

Harford, Mansi, and Maxwell (2008) investigated the relationship between cash holdings and corporate governance. According to the results, companies with more internal ownership 
and institutional ownership have more cash holdings. However, companies with higher quality, larger corporate governance, and board of directors have lower cash holdings.

Rubin (2007) investigated the relationship between the liquidity of a company's stock and its ownership structure, especially, how much of the company's stock is owned by insiders and institutions and how concentrated is their ownership. He found that liquidity-ownership relation is mostly driven by institutional ownership rather than insider ownership. Importantly, liquidity is positively related to the total institutional holdings but negatively related to the institutional blockholdings.

Kapopoulos and Lazaretou (2007) studied corporate ownership structure and firm performance through the information of 175 Greek companies; they found that more concentrated ownership structure positively related to higher company profitability. Moreover, higher company profitability required a less diffused ownership.

Zhao and Millet-Reyes (2007) in their research investigated the impact of family and bank ownership on the accounting information content of French firms from 1994 to 1998. They found that in family-controlled firms, the accounting information content of earnings is low. However, bank-controlled firms reported earnings that are more persistent.

Khaola Saddor (2006, as cited in Akhavan, Shekarchizadeh, Abasaltian, \& Abasaltian, 2015) examined cash flow determinants in French companies. He found that when their activities are at high risk and the cash flow levels are high, they increase their cash funds and then they mitigate it when they have a lot of financial leverage. Compared to mature companies, growing companies maintain more cash funds.

Osta (2011) in a research investigated the impact of ownership structure on earnings management. In this study, ownership structure has been categorized into four groups of institutional, corporate, managerial and foreign ownership. In the sample of this research, there was no information about the ownership of foreign investors, thus this kind of ownership was not investigated. The statistical population included 95 companies accepted in Tehran Stock Exchange from 2004 to 2008. The results indicated that there is a negative and significant relationship between institutional and managerial ownership and earnings management. Moreover, there was a positive and significant relationship between corporate ownership and earnings management.

Rasaian et al. (2011) studied the impact of some of the mechanisms of corporate governance including the percentage of non-executive board of directors and the percentage of institutional investors as independent variables and the level of cash holdings as the dependent variable in Tehran Stock Exchange. According to the results, there was a negative and significant relationship between the percentage of non-executive board of directors and the level of cash holdings in Tehran Stock Exchange. However, there was no significant relationship between the percentage of institutional investors and the level of cash holdings.

Ghorbani and Adili (2012) investigated the relationship between cash holdings and firm value under information asymmetry. The statistical population included all the companies accepted in Tehran Stock Exchange. One hundred five companies were selected as sample from 2003 to 2008. The results showed that under information asymmetry, there was a significant and reverse relationship between cash holdings and firm value. The findings confirmed the theory of free cash flow. 
Aghaee et al. (2009) selected 283 companies as sample from 2000 to 2005 through interim financial statements and investigated the effective factors in reserving cash in hand in the companies accepted in the Tehran Stock Exchange. The results indicated that accounts receivable, net working capital, inventories of goods, and short-term debts are respectively the factors which have the most negative effect on cash holdings. The opportunities for company's development, dividend, cash flows volatility, and net profit are respectively the factors which have the most positive effect on cash holdings. However, there is no enough evidence for the negative effect of long-term debts and companies' size on cash holdings.

Fazlzadeh et al. (2008) conducted a research with the aim of determining the effect of ownership structure on firm performance. The findings indicate that ownership concentration does not have a significant effect on firm performance, but the effects of institutional ownership and the concentration of institutional ownership are significant. The results also show that this effective relationship is adjusted with the arrival of industry. The results of this research clarify the role of ownership structure in firm performance and provide perspectives for policy-makers to improve the system of corporate governance.

Namazi and Kermani (2009) investigated the effect of ownership structure on the performance of the companies accepted in the Tehran Stock Exchange. Sixty six companies from 2003 to 2007 were studied and the findings indicated that there was a negative and significant relationship between institutional ownership and company's performance and a positive and significant relationship between corporate ownership and company's performance. Moreover, managerial ownership has a significant negative impact on the performance. Concerning foreign ownership, there was no information on the ownership of foreign investors in the companies of statistical sample and regarding private ownership, it is better if the major ownership is available to corporate investors. Generally, there is a significant relationship between companies’ ownership structure and their performance.

\section{Research Hypotheses}

The main goal of this study is to investigate the relationship between ownership structure and the level of cash holdings in the companies accepted in Tehran Stock Exchange. It is an expost facto research. In such a research, the goal is to investigate the relationship between variables and the data is collected and analyzed from a natural environment or from previous events which have occurred without the direct interference of the researcher. This study is also correlational and the main goal is to investigate whether there is a relationship between two or more variables or not and if there is, how it is. In case there is a relationship between ownership structure and the level of cash holdings in the companies, the effective factors will be identified. According to the goal of research, the following hypotheses are presented:

$\mathbf{H}_{\mathbf{0 1}}$ : There is a significant relationship between company's institutional ownership and the level of cash holdings.

$\mathbf{H}_{\mathbf{0 2}}$ : There is a significant relationship between company's managerial ownership and the level of cash holdings.

$\mathbf{H}_{\mathbf{0 3}}$ : There is a significant relationship between company's corporate ownership and the level of cash holdings. 
$\mathbf{H}_{\mathbf{0 4}}$ : There is a significant relationship between company's foreign ownership and the level of cash holdings.

\section{Method}

In this research, the statistical population includes the companies accepted in Tehran Stock Exchange over a ten-year period from 2004 to 2013 and the data was gathered annually. The study suffers from some drawbacks; in order to homogenized the statistical sample during these years, the companies must be accepted before 2004 in Tehran Stock Exchange; to increase the ability of comparison, their fiscal period must be terminated in the month of Esfand (from the middle of February to the middle of March); there must not be any kind of change in activity or fiscal year during the mentioned years; the data must be available; and the selected companies must not be banks or of investing kind. Considering the mentioned limitations, from the companies accepted in Tehran Stock Exchange, ninety six companies were selected.

\section{The Conceptual Model of the Research}

The conceptual model of the theories and concepts that are relevant to the study is depicted in equation 1.

Equation 1:

$$
M o c=\alpha_{0}+\alpha_{1} I o+\alpha_{2} M o+\alpha_{3} c o+\alpha_{4} F o+\alpha_{5} m v+\alpha_{6} c a s h-f l o w+\alpha_{7} d e b t
$$

In this equation, $\mathrm{MOC}, \mathrm{IO}, \mathrm{MO}, \mathrm{CO}, \mathrm{FO}$, and $\mathrm{MV}$ refers to the level of cash holdings, institutional ownership, managerial ownership, corporate ownership, foreign ownership, and market value, respectively.

\section{Results}

\section{Descriptive Statistics}

The descriptive statistics of variables are summarized in Table 1.

Table 1

Descriptive Statistics for Variables

\begin{tabular}{llll}
\hline Companies & $n$ & $M$ & $S D$ \\
\hline MOC & 960 & 04 & .04 \\
CO & 960 & .19 & .07 \\
FO & 960 & .03 & .05 \\
IO & 960 & .05 & .04 \\
MO & 960 & .71 & .10 \\
MV & 960 & .04 & .08 \\
CASH FLOW & 960 & .18 & .29 \\
DEBT & 960 & .95 & .01 \\
\hline
\end{tabular}

Table 2 shows the results of estimating EGLS regression in different companies. 
Table 2

The Results of Multiple Regression Analyses for Cash Holdings

\begin{tabular}{lcc}
\hline & & Model \\
\cline { 2 - 3 } Variables & $\beta$ & $t$ \\
\hline Fixed Value & $-.02^{* *}$ & 3.92 \\
Corporate Ownership & .00 & .28 \\
Foreign Ownership & $.04^{* *}$ & 4.99 \\
Institutional Ownership & $.34^{* *}$ & 17.88 \\
Managerial Ownership & $.06^{* *}$ & 16.72 \\
Market Value & .00 & 1.04 \\
Cash Flow & -.00 & -.55 \\
Debt & .00 & 5.14 \\
Adjusted $R^{2}$ & .84 & \\
$F$ for change in $R^{2}$ & 69.76 & \\
\hline
\end{tabular}

Note: Model (Department Variable: Cash Holdings); ${ }^{*} p<.05 .{ }^{* *} p<.01$

The results indicated that regression is significant in general; $F=69.76, p<.01$. The adjusted R-squared is 0.84 which is acceptable. Concerning the variable of corporate ownership, it is not significant in predicting the level of cash holdings; $\beta=.00, t=.28$. In relation to the foreign ownership variable, it is significant in predicting the level of cash holdings; $\beta=.04, t=4$.99. The institutional ownership is significant in predicting the level of cash holdings; $\beta=.34, t=17.88$. Regarding the variable of managerial ownership, it is significant in predicting the level of cash holdings; $\beta=.06, t=16.72$. The variable of market value is not significant in predicting the level of cash holdings; $\beta=.00, t=1.04$. In addition, the variable of cash flow is not significant in predicting the level of cash holdings; $\beta=-.00$, $t=-.55$. Finally, the variable of debt is not significant in predicting the level of cash holdings; $\beta=.00, t=5.14$.

\section{Discussion and Conclusion}

Since the estimations were calculated through EGLS, they are reliable in general. It is worth mentioning that in order to correct heteroscedasticity, EGLS has been conducted, thus, there is a significant relationship between company's institutional ownership and the level of cash holdings. Moreover, there is a significant relationship between company's managerial ownership and the level of cash holdings and there is a significant relationship between company's corporate ownership and the level of cash holdings. Finally, there is no significant relationship between company's foreign ownership and the level of cash holdings. According to the results of this research and the impact of different types of ownership on earnings management, it is recommended that investors consider the composition of shareholders as one of the variables of decision when they make decision about buying and selling. While studying the financial statements of the companies, the users of financial statements are recommended to notice the active or inactive monitoring role of different categories of ownership on the level of cash holdings.

Every research paves the way for new research; thus according to the topic and results of this research the following recommendations for further studies are proposed. In this study, the role of institutional, corporate, and managerial ownerships in different industries has not investigated. Therefore, the relationship between ownership structure and the level of cash 
holdings in different industries can be investigated. Moreover, the present study covers the period of 2004 to 2013. The topic of this research can be investigated in other periods with more samples and in order to increase the validity, the results of new research can be compared with the results of the present study. Finally, the impact of ownership concentration or the composition of board of directors on the level of cash holdings can be separately studied.

\section{References}

Aghaee, M., Nezafat, A., Nazemi Ardakani, M., \& Javan, A. (2009). An investigation of the effective factors in reserving cash in hand in the companies accepted in the Tehran Stock Exchange. Journal of Financial Accounting Researches, 1(1), 53-70.

Akhavan, P., Shekarchizadeh, A., Abasaltian, A., \& Abasaltian, M. (2015). Studying the effective factors on holding cash funds in the organizations: A comparative study among different theories. Applied Mathematics in Engineering, Management \& Technology, 3(2), 273-279.

Cornett, M. M., Marcus, A. J., Saunders, A., \& Tehranian, H. (2007). The impact of institutional ownership on corporate operating performance. Journal of Banking \& Finance, 31(6), 1771-1794.

Davis, E. P. (2002). Institutional investors, corporate governance and the performance of the corporate sector. Economic systems, 26(3), 203-229.

Dittmar, A., Mahrt-Smith, J., \& Servaes, H. (2003). International corporate governance and corporate cash holdings. Journal of Financial \& Quantitative Analysis, 38(1), 111-133.

Drobetz, W., Gruninger, M. C., \& Hirschvogl, S. (2010). Information asymmetry and the value of cash. Journal of banking \& Finance, 34(9), 2168-2184.

Earnhart, D., \& Lizal, L. (2006). Effects of ownership and financial performance on corporate environmental performance. Journal of Comparative Economics, 34(1), 111-129.

Fama, E. F., \& Jensen, M. C. (1983). Separation of ownership and control. Journal of Law \& Economics, 26(2), 301-325.

Fazlzadeh, A., Mohammadzadeh, P., \& Tahbaz Hendi, A. (2008). The examination of the effect of ownership structure on firm performance in listed firms of Tehran Stock Exchange based on the type of the industry. Quarterly Journal of Securities Exchange, 2(7), 5-33.

Ferreira, M. A., \& Vilela, A. S. (2004). Why do firms hold cash? Evidence from EMU countries. European Financial Management, 10(2), 295-319.

Ghorbani, S., \& Adili, M. (2012). Firm value, cash holdings and information asymmetry. Journal of Accounting Knowledge, $3(8), 131-149$.

Harford, J., Mansi, S. A., \& Maxwell, W. F. (2008). Corporate governance and firm cash holdings in the US. Journal of Financial Economics, 87(3), 535-555.

Izadinia, N., \& Rasaian, A. (2010). Corporate governance, the level of cash holdings and performance of the companies accepted in Tehran Stock Exchange. Quarterly Journal of Economic Research and Policies, 18(55), 141-154.

Jensen, M. C. (1986). Agency costs of free cash flow, corporate finance and takeovers. The American Economic Review, 76(2), 323-329.

Kaplan, S. N., \& Minton, B. A. (1994). Appointments of outsiders to Japanese boards: Determinants and implications for managers. Journal of Financial Economics, 36(2), 225-258.

Kapopoulos, P., \& Lazaretou, S. (2007). Corporate ownership structure and firm performance: Evidence from Greek firms. Corporate Governance: An International Review, 15(2), 144-158.

Keynes, J. M. (1936). The general theory of employment, interest and money. London: MacMillan.

Kumar, J. (2004). Does ownership structure influence firm value? Evidence from India. The Journal of Entrepreneurial Finance \& Business Ventures, 9(2), 61-93.

Malekian, E., \& Adili, M. (2013). Institutional ownership and cash balance. Journal of Accounting Knowledge \& Research, $8(32), 10-15$.

Namazi, M., \& Kermani, E. (2009). Investigating the effects of ownership structure on the performance of the companies accepted in the Tehran Stock Exchange. Journal of the Accounting \& Auditing Review, 15(53), 83-100. 
Opler, T., Pinkowitz, L., Stulz, R., \& Williamson, R. (1999). The determinants and implications of corporate cash holdings. Journal of Financial Economics, 52(1), 3-46.

Osta, S. (2011). An investigation of the relationship between ownership structure and earnings management. Journal of Financial Accounting Researches, 3(2), 93-106.

Ozkan, A., \& Ozkan, N. (2004). Corporate cash holdings: An empirical investigation of UK companies. Journal of Banking \& Finance, 28(9), 2103-2134.

Rasaian, A., Rahimi, F., \& Hanjari, S. (2011). The impact of inter-organizational regulatory mechanisms of corporate governance on the level of cash holdings in Tehran Stock Exchange. Journal of Financial Accounting Researches, 2(4), 125-144.

Rubin, A. (2007). Ownership level, ownership concentration and liquidity. Journal of Financial Markets, 10(3), $219-248$.

Salavati, S., \& Rasaian, A. (2007). An investigation of the relationship between capital structure and stock liquidity in Iran. Nameh-Ye-Mofid, 13(63), 143-163.

Velury, U., \& Jenkins, D. S. (2006). Institutional ownership and the quality of earnings. Journal of Business Research, 59(9), 1043-1051.

Zhao, R., \& Millet-Reyes, B. (2007). Ownership structure and accounting information content: Evidence from France. Journal of International Financial Management \& Accounting, 18(3), 223-246. 